\title{
A review of Dipbya (Aranei: Tetragnathidae) from South Africa
}

\section{Обзор пауков рода Diphya (Aranei: Tetragnathidae) Южной Африки}

\author{
Yuri M. Marusik \\ Ю.М. Марусик
}

Institute for Biological Problems of the North RAS, Portovaya Str. 18, Magadan, Russia. Email: yurmar@mail.ru Department of Zoology \& Entomology, University of the Free State, Bloemfontein 9300, South Africa Zoological Museum, Biodiversity Unit, FI-20014 University of Turku, Finland

Институт Биологических Проблем Севера ДВО РАН, ул. Портовая 18, Магадан 685000, Россия.

KEY WORDS: Araneae, Diphyini, Metainae, Tetragnathinae, new species, redescription, distribution.

КЛЮЧЕВЫЕ СЛОВА: Araneae, Diphyini, Metainae, Tetragnathinae, новый вид, переописание, ЮАР.

ABSTRACT. Three species of Diphya Nicolet, 1849 found in South Africa are surveyed. Diphya simoni Kauri, 1950, the single named species known in the country is redescribed based on the holotype female from Limpopo Province. A new species, $D$. tanikawai sp.n. (†) from Western Cape is described. One species represented by subadult specimens from Kwazulu Natal is illustrated. Distribution of the genus is mapped.

РЕЗЮМЕ: В работе рассмотрены 3 вида рода Diphya Nicolet, 1849 из ЮАР. Diphya simoni Kauri, 1950 , единственный вид известный из ЮАР переописан на основе голотипа из провинции Лимпопо. Описан новый вид, D. tanikawai sp.n. (†) из провинции Западный Кейп. Приводится иллюстрированное описание двух неполовозрелых экземпляров Diphya из провинции Квазулу Натал. Необычное распространение рода показано на карте.

\section{Introduction}

Diphya Nicolet, 1849 is a relatively small genus with only 14 valid species. It has a rather unusual distribution (Fig. 20): southern Brazil, southern Chile, southernmost Argentina, South Africa, Madagascar and South East Asia (Japan, Korea, Taiwan and northern China [WSC, 2017]. Álvarez-Padilla \& Hormiga [2011] and Marusik \& Kovblyuk [2011] also mentioned two undescribed species from Tanzania and Maritime Province of Russia, respectively.

The eye pattern easily distinguishes the genus from other Tetragnathidae: the very large eyes (all posterior and anterior lateral), widely spaced lateral eyes (anterior and posterior eyes almost touching in most of other genera). Diphya species can be easily recognized due to an anterior row of stiff inflexible setae on tibia- metatarsi I and II (similar to those found in Mimetidae or some Theridiosomatidae) and the male palp with a spine-like cymbial outgrowth.

While collecting spiders on Table Mountain in the environs of Cape Town, I collected two Diphya females. Comparison of these specimens with the holotype of Diphya simoni Kauri, 1950, from northeastern South Africa, and known so far only from the original description, reveals that specimens from Western Cape Province belong to a new species. I also found two subadult specimens of Diphya among material collected in 2012 in Kwazulu Natal. The goal of this paper is the description of a new species and redescription $D i$ phya simoni, as well as providing notes on specimens collected in Kwazulu Natal and the relationship of the genus.

\section{Material and methods}

Specimens were photographed using an Olympus Camedia E-520 camera attached to an Olympus SZX16 stereomicroscope at the Zoological Museum, University of Turku. Digital images were montaged using CombineZP image stacking software. Epigyne was cleared in a $\mathrm{KOH} /$ water solution until soft tissues were dissolved. Photographs were taken in dishes with cotton paraffin on the bottom to hold the specimens in position. All measurements are given in millimeters. Lengths of leg segments were measured on the dorsal side. Leg measurements are given in the following sequence: total (femur patella tibia metatarsus tarsus). Abbreviations used for spination and leg segments are as follows: $\mathrm{d}$ - dorsal, fe - femur, mt - metatarsus, pa patella, $\mathrm{p}$ - prolateral, $\mathrm{r}$ - retrolateral, ta - tarsus, ti - tibia, v - ventral.

Museum abbreviations: NCA - National Collection of Arachnida, Pretoria, ZMLU — Zoological Museum, Lund University, Sweden. 


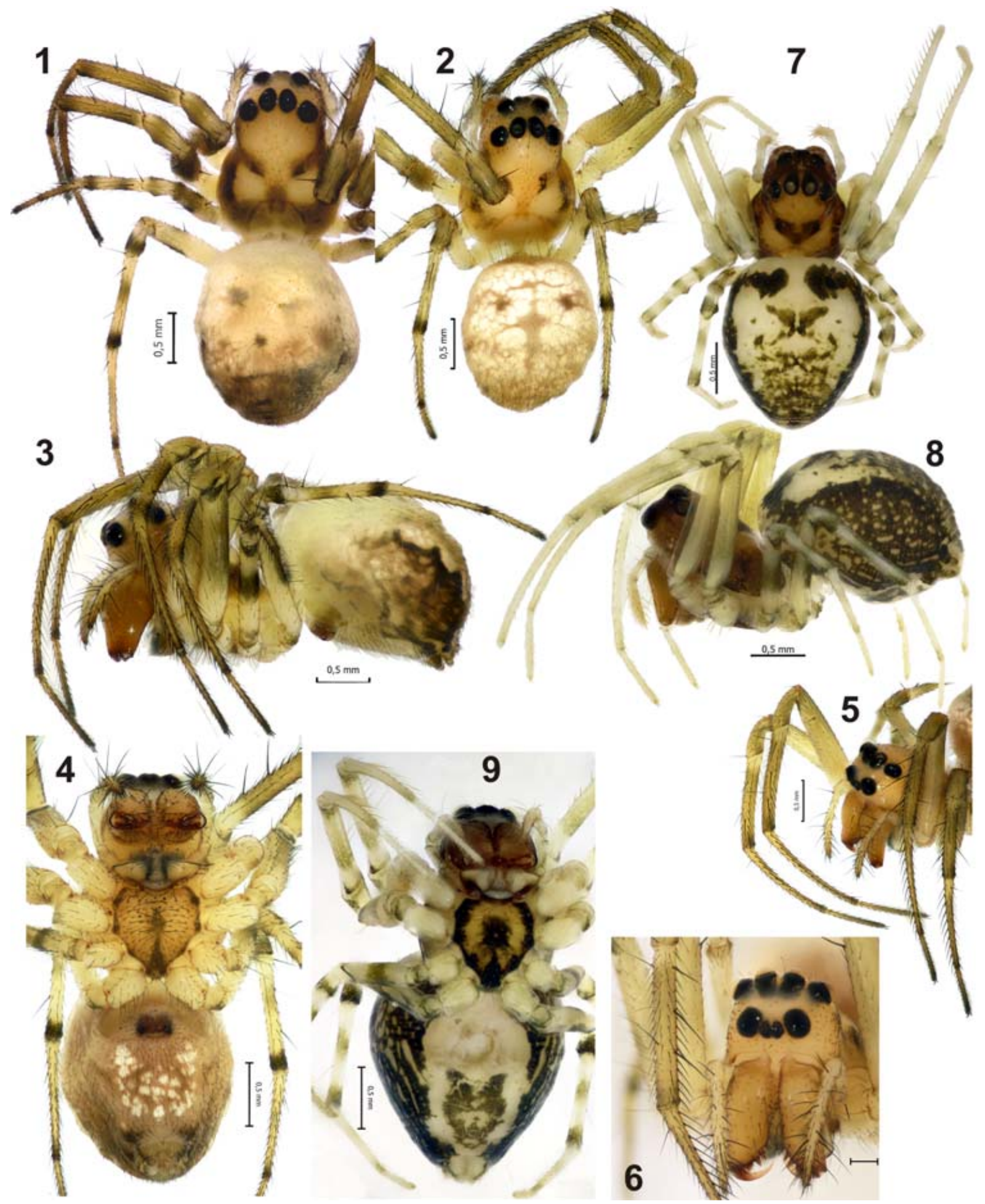

Fig. 1-9. General appearance of Diphya tanikawai sp.n. (1-6) and D. simoni (holotype, 7-9): 1-2, 7 - habitus, dorsal; 3, 8 habitus, lateral; 4, 9 - ventral; 5-6 prosoma, anterior and latero-anterior, showing eye pattern and rows of strong inflexible setae. $1,3-$ paratype; 2, 4-6- holotype.

Рис. 1-9. Внешний вид Diphya tanikawai sp.n. (1-6) и D. simoni (holotype, 7-9): 1-2, 7 - габитус, сверху; 3, 8 - габитус, сбоку; 4, 9 - габитус, снизу; 5-6 - головогрудь, спереди и сбоку-спереди, показано глазное поле и ряд шипов. 1,3 - паратип; 2 , $4-6$ - голотип. 

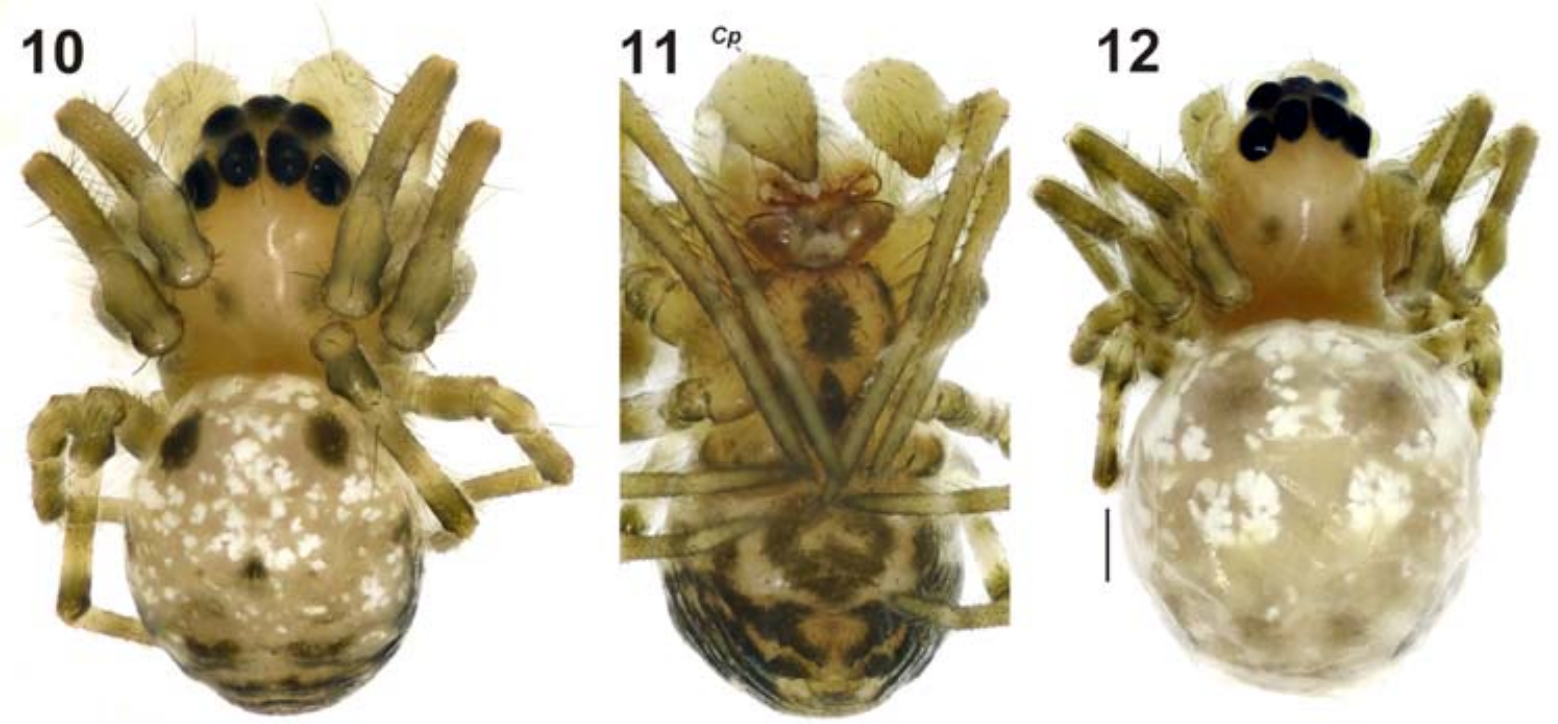

Fig. 10-12. Habitus of subadults of Diphya sp. from Kwazulu Natal: 10-11 - subadult male, dorsal and ventral; 12 - subadult female, dorsal. Scale $=0.2 \mathrm{~mm}$. Abbreviations: $C p$ undeveloped cymbial process.

Рис. 10-12. Внешний вид ювенильных Diphya sp. из Квазулу Натал: 10-11 - субадультный самец, сверху и снизу; $12-$ субадультная самка, сверху. Масштаб $=0,2$ мм. Сокращения: $C p$ зачаток отростка цимбума.

\section{Taxonomy}

Diphyini Simon, 1894

Diphyeæ Simon, 1894: 742

NOTE. Simon [1894] placed Diphyeæ in Tetragnathinae. At that time Tetragnathidae was considered as subfamily of Araneidae. Besides Diphyeæ Simon [1894] defined other tribes in Tetragnathinae: Meteæ (based on Meta C.L. Koch, 1836), Aziliaæ (based on Azilia Keyserling, 1881), Pachygnatheæ (based on Pachygnatha Sundevall, 1823, now considered to belong to the Tetragnathinae), as well as Nesticeæ and Cyatolipeæ (now considered as separate families).

The status of Diphyini has not previously been discussed and it has not so far been mentioned in any publication even dealing with groupings in the Tetragnathidae.

COMPOSITION. Simon [1894] included two genera in Diphyini, Diphya and Dolichognatha O. Pickard-Cambridge, 1869.

\section{Diphya Nicolet, 1849}

Diphya Nicolet, 1849: 406; Simon, 1894: 744; Tullgren ,1902: 24; Tanikawa, 1995: 102; Álvarez-Padilla, Hormiga, 2011: 756.

Type species: Diphya macrophthalma Nicolet, 1849, from southern Chile.

NOTE. The genus was globally revised by Tanikawa [1995] and recently it was re-diagnosed by Álvarez-Padilla \& Hormiga [2011]. The genus description made by Álvarez-Padilla \& Hormiga [2011] was based on D. spinifera Tullgren, 1902 from Chile. ÁlvarezPadilla \& Hormiga [2011] indicated female body length as "c. $0.5 \mathrm{~mm}$ ", while Tullgren [1902] mentioned that length of the female is $4.2 \mathrm{~mm}$. The total length of all species considered in the genus (based on literature data) is $2.3-4.2 \mathrm{~mm}$.

Exact placement of Diphya within Tetragnathidae remains uncertain. There are several recent publications discussing the relationships of tetragnathids and Diphya particularly [Álvarez-Padilla 2007; ÁlvarezPadilla et al. 2009; Álvarez-Padilla \& Hormiga 2011]. For some reason Simon's [1894] taxa Diphyini and Aziliini are not discussed there. Álvarez-Padilla [2007] placed Diphya in the Tetragnathinae, but later ÁlvarezPadilla et al. [2009] considered genus in the Metainae (replacement name for Metinae). Álvarez-Padilla \& Hormiga [2011] kept Diphya unplaced in any suprageneric taxon, but proposed it as a sister to the Tetragnathinae.

ECOLOGY. There are no literature data about the natural history of Diphya species. Diphya tanikawai sp. n. as well as Diphya sp. from Kwazulu Natal were collected on the ground among grass. Undescribed $D i$ phya from the Russian Far East was collected either amongst reeds or grass. Most likely they do not build webs but catch their prey with help of a "basket" formed by the spiny first pair of legs. Shinkai [2006: 166] observed and photographed the web of Diphya okumae Tanikawa, 1995 in Japan. This species makes a web close to the ground.

\section{Species survey}

\section{Diphya tanikawai sp.n.}

Figs 1-6, 13-18

Diphya capensis Simon, 1894: 744 (nomen nudum); Bonnet, 1956: 1477 (marked as nomen nudum). 

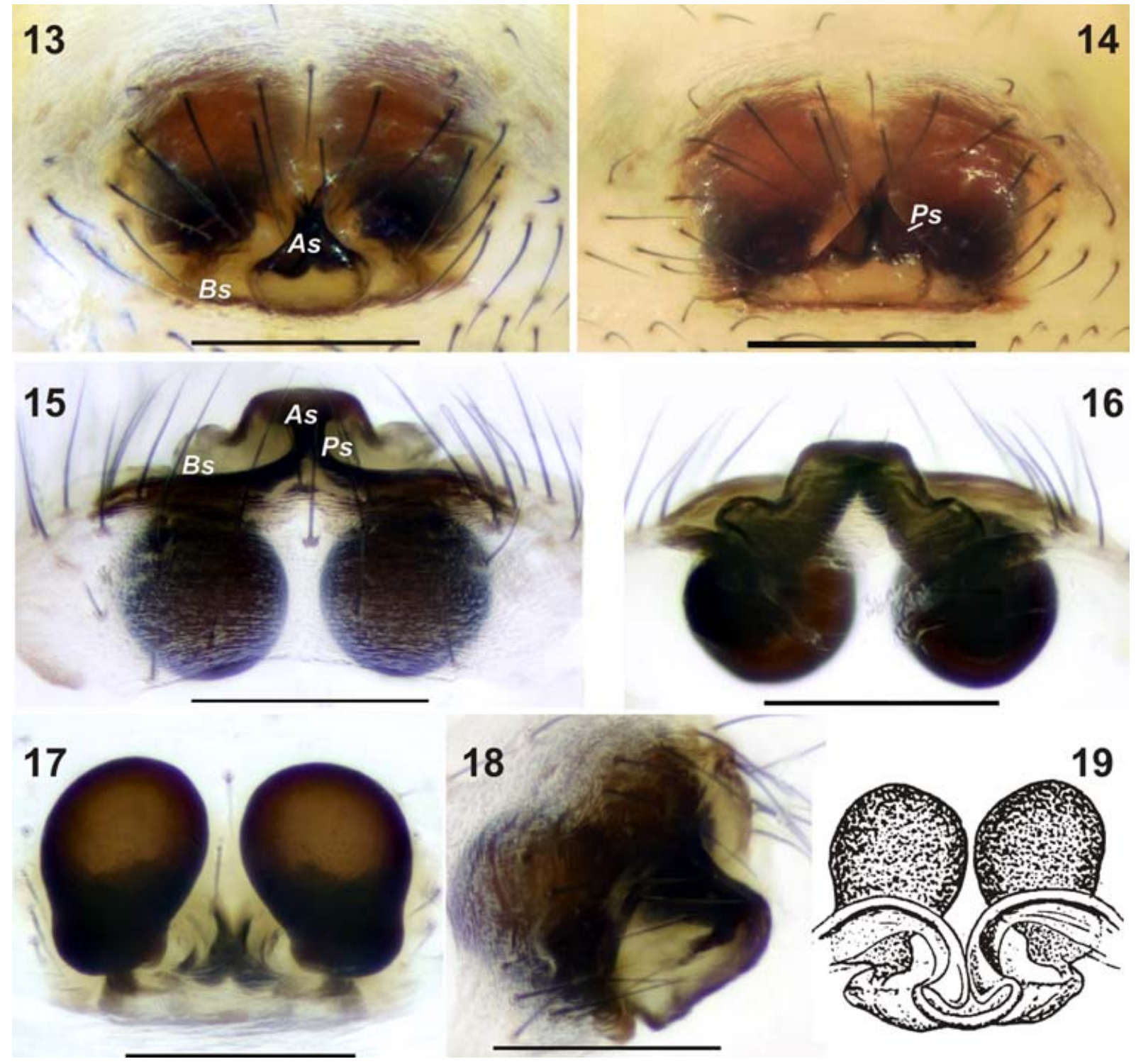

Fig. 13-19. Epigyne of holotypes of Diphya tanikawai sp.n. (13-18) and D. simoni (19): 13-14 — intact epigyne, ventral and ventrocaudal; 15-16, 19 - macerated epigyne, anterior and posterior; 17-18 - macerated epigyne, dorsal and ventro-lateral. 19 - after Kauri [1950]. Scale $=0.2 \mathrm{~mm}$ if indicated. Abbreviations: $A s$ - anterior part of septum, $B s$ - basal part of septum, $P s$ - pockets of $A s$.

Рис. 13-19. Эпигина голотипов Diphya tanikawai sp.n. (13-18) и D. simoni (19): 13-14 - интактная эпигина, снизу и снизусзади; 15-16, 19 - очищенная эпигина, спереди и сзади; 17-18 - очищенная эпигина, сверху и снизу-сбоку. 19 - по Kauri [1950]. Масштаб = 0,2 мм, если указан. Сокращения: $A s$ - передня часть септума $B s$ - базальная часть септума, $P s$ - карманы $A s$.

TYPES. Holotype $q$ (NCA) and paratype $q(\mathrm{NCA})$, South Africa, Western Cape, Cape Town, Table Mt, ca 950-1000 m, $33.9608^{\circ} \mathrm{S}, 18.408307^{\circ} \mathrm{E}$, Platteklip Gorge, among moist grass, 29.01.2017 (Yu.M. Marusik)

ETYMOLOGY. The specific name is a patronym in honour of Akio Tanikawa (Tokyo, Japan), a well known expert in araneoid spiders who revised the genus.

DIAGNOSIS. It is most similar to D. simoni Kauri, 1950, known from Limpopo Province of South Africa. Diphya tanikawai sp.n. differs by lighter colouration, patterns of sternum, carapace and abdomen (cf. Figs 1-4 and 7-9). The two species can most easily be separated by the venter of abdomen having white guanine spots in the new species which are lacking in D. simoni. At the same time $D$. simoni has wide blackish mark on the venter of abdomen which is lacking in the new species. Both species have similar shaped epigynes (cf. Figs 1317 and 19), but because the epigyne in the holotype of D. simoni was lost I cannot compare them in detail.

DESCRIPTION. Female (holotype). Total length 3.25. Carapace 1.63 long, 1.15 wide; yellow brown, with dark brown spots behind the cephalic area, and short submarginal band in the thoracic part. Chelicera and mouth parts colored as carapace. Chelicera with 3 promarginal and 4 retromarginal teeth. Sternum yel- 


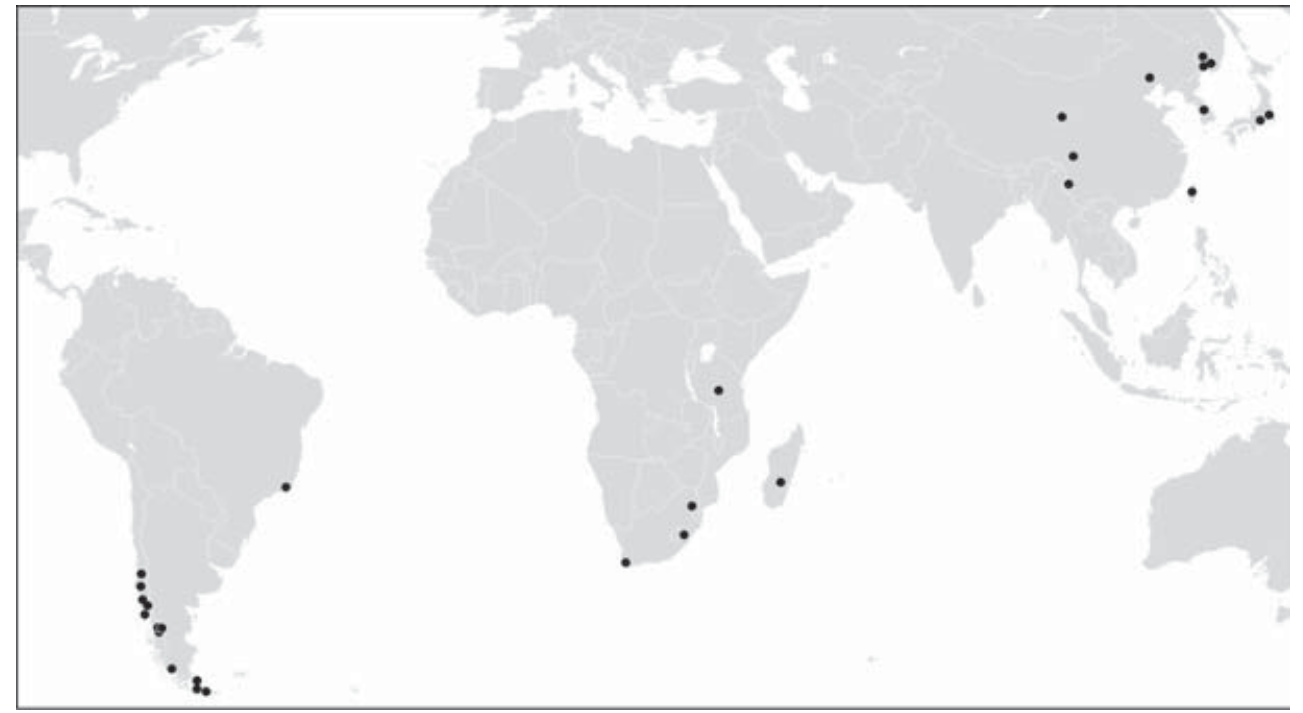

Fig. 20. Global distribution of Diphya.

Рис. 20. Распространение рода Diphya.

low-brown patterned with a median dark band and marginal dark stripes. Legs lighter than carapace, with almost indistinct dark rings on the tibia-tarsi of legs I and II. The dark rings more distinct on legs III and IV. Abdomen whitish dorsally due to white guanine spots, with a pair of dark spots anteriorly; sides with blackish pigmentation; venter yellow-brown with white guanine spots between epigastrum and spinnerets. Spination of leg I (only flexible spines are indicated): femur p1; patella d1; tibia d2 p3 r1; metatarsus d1. Legs length: palp $1.46(0.43+0.18+0.35+0.5)$, I $5.5(1.43+0.59+$ $1.25+1.40+0.83)$, II $4.99(1.40+0.53+1.08+1.25+$ $0.73)$, III $2.94(0.88+0.35+0.60+0.68+0.43)$, IV $4.08(1.38+0.40+0.85+0.95+0.50)$.

Epigyne as in Figs 13-18. Plate of epigyne about 1.5 wider than long, septum $(\mathrm{Se})$ triangular in ventralposterior view (Fig. 18) or droplet-shaped in ventral view (Fig. 13) composed of a transverse, weakly sclerotised basal part $(B s)$ and heavily sclerotised anterior part $(A s)$ bearing pockets $(P s)$; the anterior part extended ventrally (Fig. 18); receptacles round in anterior view, closely spaced (about $1 / 6$ of diameter).

Male unknown.

NOTE. Simon [1894] while writing of the distribution of the genus mentioned in the text "Africa max. austr. (capensis E. Sim.)". Such "species" labeled as Diphya capensis are housed in the Muséum National d'Histoire Naturelle [Kauri, 1950] but the species was never described.

DISTRIBUTION AND HABITAT. The species is known from the type locality. Both specimens were collected among long grass in a moist, shaded gorge.

Diphya simoni Kauri, 1950

Figs 7-9, 19

Diphya simoni Kauri, 1950: 8, f. 6 (+); Tanikawa, 1995: 110.
TYPE. Holotype + (ZMLU, type no. 195: 1, reg. no. L948/ 3291), "South Africa, Transvaal, Pretorius Kop Camp, Krüger National Park, 4.11.1948 (Bertil Hanström)”. Holotype without epigyne, dissected epigyne was not found. Current name of Transvaal is Limpopo Province.

DIAGNOSIS. Diphya simoni differs from D. tanikawai sp. n. by the shape of abdomen, colouration and pattern (cf. Figs 1-4 and 7-9). The posterior end of the abdomen is pointed $v$ s. oval in D. tanikawai sp.n. The eye field darkened vs. light coloured. The two species can be easily separated by the ventral abdominal pattern, D. simoni has a dark median spot and lacks the white guanine spots, while D. tanikawai sp. n. has white guanine spots and lacks the black spot. Differences in epigynes are not clear because of the loss of the epigyne in the holotype.

DESCRIPTION. Female (holotype). Total length 3.0. Carapace 1.63 long, 1.13 wide.

Chelicera with 3 promarginal and 4 retromarginal teeth. Spination of legs (inflexible arranged in prolateral row not counted): I fe $1 p$, ti $1 d 2 p$; II fe $1 d$, $1 r$, ti $1 p$, 1r; III fe 1d, pt 1d; IV pt 1d, ti 1d 1p.Legs length: palp $1.35(0.43+0.15+0.30+0.48)$, I $5.09(1.38+0.60+$ $1.15+1.28+0.68)$, II $4.69(1.33+0.55+1.05+1.13+$ $0.63)$, III $2.93(0.90+0.35+0.55+0.68+0.45)$, IV $3.79(1.15+0.38+0.80+0.93+0.53)$. Epigyne as in Fig. 19.

Male unknown.

NOTE. Kauri [1950] indicated the length of the holotype as $3.1 \mathrm{~mm}$, and the length of carapace as 1.8 $\mathrm{mm}$ which is somewhat longer than I have observed.

Diphya sp.

Figs 10-12.

MATERIAL EXAMINED. 1 subad. $\sigma^{7}$ and 1 subad. $q$, South Africa, KwaZulu-Natal, Ntshoni Massif, $20 \mathrm{~km} \mathrm{~W}$ of Pietermaritzburg, 2936' $3^{\prime \prime} \mathrm{S}, 30^{\circ} 8^{\prime} 48^{\prime \prime} \mathrm{E}, 1350 \mathrm{~m}, 28.12 .2013$ (Yu.M. Marusik). 
NOTE. The two subadult specimens male and female have pattern similar to both Diphya species known from South Africa by adults. They have distinct guanine spots like in D. tanikawai sp. n. but only on the dorsum of abdomen, and instead of guanine spots on venter they have black median spot like in $D$. simoni. The carapace pattern differs from both species, while pattern of the sternum resembles that of $D$. simoni. The immature male already have a rudimentary cymbial process ( $C p$, Fig. 11), as seen in all species of Diphya.

Both specimens are of small size, total length 1.75 and carapace about 0.85 . Because of the small size they are not likely to be conspecific with either $D$. tanikawai sp.n. or D. simoni.

ACKNOWLEDGEMENTS. I thank Seppo Koponen who arranged my stay in Turku and work in Zoological Museum and Maria Mostadius (ZMLU) for sending the holotype of D. simoni. I am indebted to Akio Tanikawa (Tokya, Japan) and Zhang Feng (Baoding, China) for reviewing manuscript and valuable comments. English of the earlier draft was kindly checked by Astri Leroy (Johannesburg, South Africa). English of the final draft was checked by Done Bukle (Saskatoon, Canada).

\section{References}

Álvarez-Padilla F. 2007. Systematics of the spider genus Metabus O. P.-Cambridge, 1899 (Araneoidea: Tetragnathidae) with additions to the tetragnathid fauna of Chile and comments on the phylogeny of Tetragnathidae // Zoological Journal of the Linnean Society. Vol.151. P.285-335.

Álvarez-Padilla F., Dimitrov D., Giribet G., Hormiga G. 2009. Phylogenetic relationships of the spider family Tetragnathidae (Araneae, Araneoidea) based on morphological and DNA sequence data // Cladistics. Vol.25. P.109-146.

Álvarez-Padilla F., Hormiga G. 2011. Morphological and phylogenetic atlas of the orb-weaving spider family Tetragnathidae (Araneae: Araneoidea) // Zoological Journal of the Linnean Society. Vol.162. P.713-879.

Bonnet P. 1956. Bibliographia araneorum. Toulouse: Douladure. T.2. Pt.2. P.919-1926.

Kauri H. 1950. On some South African spiders and harvest-spiders // Kungliga Fysiografiska Sällskapets i Lund Förhandlingar // Vol.20. No.6. P.1-16.

Marusik Yu.M., Kovblyuk M.M. 2011. [Spiders (Arachnida, Aranei) of Siberia and Russian Far East]. Moscow: KMK Scientific Press. 344 pp. [in Russian]

Nicolet A.C. 1849. Aracnidos // Gay C. (ed.). Historia física y política de Chile. Zoología. Vol.3. P.319-543.

Shinkai E. 2006. Spiders of Japan. Tokyo: Bun-ichi Sogo Shuppan. 335 pp.

Simon E. 1894. Histoire naturelle des araignées. Paris. T.1. P.489760.

Tanikawa A. 1995. Two new species of the spider genus Diphya (Araneae: Tetragnathidae) from Japan and Taiwan, with notes on the known species // Acta Arachnologica. Vol.44. No.2. P.101-111.

Tullgren A. 1902. Spiders collected in the Aysen Valley by Mr P. Dusén // Bihang till Kungliga Svenska Vetenskaps-Akademiens Handlingar. Bd.28. Afd.4. No.1. P.1-77.

World Spider Catalog 2017. World Spider Catalog. Natural History Museum Bern, online at http://wsc.nmbe.ch, version 18.0.

Responsible editor: K.G. Mikhailov 